Temper at ur e- dependent Speci f i c Transport of Levof I oxaci n i n Human I nt est i nal Epi thel i al LS180 Cel I s

\begin{tabular}{|l|l|}
\hline 著者 & $\begin{array}{l}\text { FUKUMORI Shi ro, MASAGO M ki , I SH DA Kazuya, } \\
\text { KAYANO Yui chi ro, TAGUTH Nasat o, HASH MOTO } \\
\text { Yuki ya }\end{array}$ \\
\hline $\begin{array}{l}\text { j our nal or } \\
\text { publ i cat i on t i t l e }\end{array}$ & Bi ophar maceut i cs \& Drug Di sposi t i on \\
\hline vol une & 30 \\
\hline number & 8 \\
\hline page r ange & 448 456 \\
\hline year & 2009 \\
\hline URL & ht t p: //hdl . handl e. net /10098/2506 \\
\hline
\end{tabular}




\title{
Temperature-dependent Specific Transport of Levofloxacin in Human Intestinal Epithelial LS180 Cells
}

\author{
Shiro Fukumori, Miki Masago, Kazuya Ishida, Yuichiro Kayano, Masato Taguchi and Yukiya Hashimoto* \\ Graduate School of Medicine and Pharmaceutical Sciences, University of Toyama, 2630 Sugitani, Toyama 930-0194, Japan
}

\begin{abstract}
It was reported previously that specific levofloxacin uptake in Caco-2 cells was inhibited by nicotine, enalapril, L-carnitine and fexofenadine. The aim of the present study was to characterize the cellular uptake of levofloxacin using another human intestinal cell line, LS180. Levofloxacin uptake in LS180 cells was temperature-dependent and optimal at neutral pH, but was $\mathrm{Na}^{+}$-independent. The rank order of inhibitory effects of the four compounds on $\left[{ }^{14} \mathrm{C}\right]$ levofloxacin uptake in LS180 cells was nicotine $>$ enalapril $>$ L-carnitine $>$ fexofenadine, which is consistent with that in Caco-2 cells. The mRNA levels of OATP1A2, 1B1, 1B3 and 2B1 in LS180 cells were markedly different from those in Caco-2 cells, and OATP substrates/inhibitors had no systematic effect on the levofloxacin uptake. The mRNA levels of OCTN1 and 2 in LS180 cells were similar to those in Caco-2 cells. However, the inhibitory effect of nicotine on L- $\left[{ }^{3} \mathrm{H}\right]$ carnitine uptake was much less potent than that of unlabeled L-carnitine. These results indicate that the specific uptake system for levofloxacin in LS180 cells is identical/similar to that in Caco-2 cells, but that OATPs and OCTNs contribute little to levofloxacin uptake in the human intestinal epithelial cells. Copyright (C) 2009 John Wiley \& Sons, Ltd.
\end{abstract}

Key words: levofloxacin; OATP; OCTN; LS180 cells; Caco-2 cells

\section{Introduction}

Levofloxacin is well absorbed from the intestine, and the bioavailability following oral administration is approximately $100 \%$ in humans [1]. Since levofloxacin is a zwitterionic compound, a passive diffusion mechanism may not explain fully the high intestinal absorption [1]. Yamaguchi et al. reported that apical uptake of levofloxacin in human intestinal epithelial Caco-2 cells was markedly decreased by lowering the temperature $\left(4^{\circ} \mathrm{C}\right)$ and showed concentration-dependent saturation [2]. In order to evaluate the membrane transport responsible for intestinal absorption of levofloxacin, pharmacokinetic analysis of the transcellular transport of levofloxacin across Caco-2 cell

*Correspondence to: 2630 Sugitani, Toyama 930-0194, Japan. E-mail: yukiya@pha.u-toyama.ac.jp monolayers grown on porous membrane filters was performed previously [3]. The apical influx clearance value of levofloxacin was greater than the basolateral influx clearance value in Caco-2 cells [3]. In addition, the apical uptake of $\left[{ }^{3} \mathrm{H}\right]$ glycylsarcosine (Gly-Sar) in Caco-2 cells was significantly inhibited by Ala-Ala, whereas that of $\left[{ }^{14} \mathrm{C}\right]$ levofloxacin was not inhibited by Ala-Ala and Gly-Sar [4]. On the other hand, the apical uptake of $\left[{ }^{14} \mathrm{C}\right]$ levofloxacin in Caco-2 cells was significantly inhibited by several structurally unrelated compounds, such as nicotine, fexofenadine, enalapril and L-carnitine. These results suggested that levofloxacin uptake across the apical membrane in Caco-2 cells was mediated by a specific transport system other than the peptide transport system [4]. The primary aim of the present study was to examine whether the specific transport system for levofloxacin is present in another human intestinal epithelial cell line, LS180, which is a microvillus-expressing cell line 
that possesses characteristics of the small intestine, and has been used as an in vitro model of the intestine [5-9]. In addition, the inhibitory effects of the four compounds (nicotine, fexofenadine, enalapril and L-carnitine) on the uptake of $\left[{ }^{14} \mathrm{C}\right]$ levofloxacin in LS180 cells were compared with those in Caco-2 cells.

Nicotine consists of a pyridine and an $N$-methyl pyrrolidine ring, thereby being a cyclic tertiary amine; however, there has been limited information about the intestinal transport of nicotine [10]. On the other hand, fexofenadine is a selective histamine $\mathrm{H}_{1}$ receptor antagonist and a zwitterion which contains a carboxyl group and a piperidino group [11]. Organic anion transporting polypeptide 1A2 (OATP1A2) mediated fexofenadine uptake in single-transfected HeLa cells [12]. Enalapril is an angiotensin-converting enzyme (ACE) inhibitor and a modified Ala-Pro, which consists of a free carboxylic acid moiety and an amide bond [13]. OATP1B1 and OATP1B3 are involved in the transport of enalapril in single-transfected HEK 293 cells, whereas the intestinal peptide transporter (PEPT1) may contribute little to the intestinal absorption of enalapril $[14,15]$. On the other hand, L-carnitine exists in vivo as a zwitterion, and is a highly hydrosoluble compound with a quaternary amine and a carboxylic acid moiety [16]. The uptake of L-carnitine in Caco-2 cells is primarily mediated by the organic cation transporter novel type 2 (OCTN2), and OCTN1 expressed in the human intestine is also capable of transporting L-carnitine [16,17]. The secondary aim of the present study was to investigate the involvement of OATPs and/or OCTNs in the specific transport of levofloxacin in LS180 cells. That is, the effects of OATP substrates/inhibitors and also carboxylate-type compounds on the cellular uptake of $\left[{ }^{14} \mathrm{C}\right]$ levofloxacin were evaluated in LS180 cells. In addition, the uptake characteristics of L-carnitine in LS180 cells were compared with those of levofloxacin.

\section{Materials and Methods}

\section{Materials}

$\left[{ }^{14} \mathrm{C}\right]$ Levofloxacin $(2.43 \mathrm{MBq} / \mathrm{mg})$ was kindly donated by Daiichi Pure Chemicals Co.

Copyright (C) 2009 John Wiley \& Sons, Ltd.
(Ibaraki, Japan). L-[N-Methyl- $\left.{ }^{3} \mathrm{H}\right]$ carnitine hydrochloride (L- $\left[{ }^{3} \mathrm{H}\right]$ carnitine) $(3145 \mathrm{GBq} / \mathrm{mmol})$ and $\left[{ }^{3} \mathrm{H}\right]$ mannitol $(740 \mathrm{GBq} / \mathrm{mmol})$ were purchased from American Radiolabeled Chemicals Inc. (St Louis, MO, USA). $\left[{ }^{14} \mathrm{C}\right]$ Mannitol $(1.96 \mathrm{GBq} / \mathrm{mmol})$ was purchased from Moravek Biochemicals Inc. (Brea, CA, USA). Levofloxacin hydrochloride was purchased from LKT Laboratories (St Paul, MN, USA). L-Carnitine hydrochloride and Dulbecco's modified Eagle's medium (DMEM) were acquired from Nacalai Tesque (Kyoto, Japan). Fetal bovine serum (FBS) was acquired from Biowest Inc. (Nuaille, France). All other chemicals were of the finest grade available.

\section{Cell culture}

LS180 cells at passage number 38 were obtained from the American Type Culture Collection (Manassas, VA, USA). The cells were maintained by serial passage in plastic dishes with DMEM supplemented with $10 \%$ heat-inactivated FBS, $100 \mu \mathrm{M}$ nonessential amino acids, 100 units $/ \mathrm{ml}$ penicillin $\mathrm{G}$ and $100 \mu \mathrm{g} / \mathrm{ml}$ streptomycin in an atmosphere of $5 \% \mathrm{CO}_{2}-95 \%$ air at $37^{\circ} \mathrm{C}$ [8]. The cell lines were seeded at a density $5 \times 10^{5}$ cells $/ \mathrm{cm}^{2}$ on a $3.8 \mathrm{~cm}^{2}$ plastic dish using a Falcon ${ }^{\circledR}$ multiwell ${ }^{\mathrm{TM}}$ plate (BD Bioscience, Bedford, MA, USA), and maintained for 7 days. All experiments were conducted with LS180 cells between passages 54 to 69 .

Caco- 2 cells at passage number 43 were obtained from the Riken Bioresource Center (Tsukuba, Japan). To determine mRNA expression of transporters in Caco- 2 cells, the cells were maintained for 21 days [6]. All experiments were conducted with Caco- 2 cells between passages 62 to 66 .

Real-time PCR assay of solute carrier transporter mRNA in Caco-2 and LS180 cells

Total RNA was isolated from Caco-2 and LS180 cells using an RNA extraction kit (RNeasy ${ }^{\circledR}$ Mini Kit, Qiagen, Valencia, CA, USA) according to the manufacturer's instructions [8]. Reverse transcription of extracted total RNA was performed as described previously [8]. Real-time PCR was carried out on an Mx3000 ${ }^{\circledR}$ QPCR System (Stratagene, La Jolla, CA, USA) using SYBR ${ }^{\circledR}$ Premix Ex Taq ${ }^{\mathrm{TM}}$ (TaKaRa, Shiga, Japan) according

Biopharm. Drug Dispos. 30: 448-456 (2009) DOI: $10.1002 /$ bdd 
to the manufacturer's instructions. The sequences of the specific primers have been reported elsewhere $[12,18,19]$. Cycling conditions were 1 cycle for $30 \mathrm{~s}$ at $95^{\circ} \mathrm{C}$, followed by 45 cycles of $5 \mathrm{~s}$ denaturation at $95^{\circ} \mathrm{C}, 20 \mathrm{~s}$ annealing at $60^{\circ} \mathrm{C}$ and $15 \mathrm{~s}$ extension at $72^{\circ} \mathrm{C}$ [8]. The mRNA level of transporters was normalized according to the GAPDH mRNA level, and the ratio is presented using a common logarithm.

\section{Uptake of levofloxacin in LS180 cells}

The cellular uptake of $\left[{ }^{14} \mathrm{C}\right]$ levofloxacin was examined using LS180 cells grown on plastic dishes of multiwell plates. The composition of the incubation medium was as follows: $125 \mathrm{~mm}$ $\mathrm{NaCl}, 4.8 \mathrm{mM} \mathrm{KCl}, 5.6 \mathrm{~mm}$ D-glucose, $1.2 \mathrm{~mm}$ $\mathrm{CaCl}_{2}, 1.2 \mathrm{mM} \quad \mathrm{KH}_{2} \mathrm{PO}_{4}, 1.2 \mathrm{~mm} \quad \mathrm{MgSO}_{4} \cdot 7 \mathrm{H}_{2} \mathrm{O}$ and $25 \mathrm{~mm}$ HEPES ( $\mathrm{pH} 6.0$ ), and the $\mathrm{pH}$ of the medium was adjusted with a solution of $\mathrm{NaOH}$. The cells were first pre-incubated for $15 \mathrm{~min}$ at $37^{\circ} \mathrm{C}$ with $2 \mathrm{ml}$ incubation medium containing unlabeled $20 \mu \mathrm{M}$ levofloxacin to equilibrate the drug concentration. After the pre-incubation period, the incubation medium was replaced with $0.5 \mathrm{ml}$ fresh incubation medium containing $\left[{ }^{14} \mathrm{C}\right]$ levofloxacin $(0.1 \mu \mathrm{Ci} /$ well $)$. After the cells were incubated with $\left[{ }^{14} \mathrm{C}\right]$ levofloxacin for another $5-30 \mathrm{~min}$ at $37^{\circ} \mathrm{C}$, they were immediately washed with ice-cold phosphate buffer and collected. Radioactivities in the cells were determined using a liquid scintillation counter and normalized against the initially applied doses. To estimate the extracellular trapping of the radiolabeled drug, the amount of $\left[{ }^{3} \mathrm{H}\right]$ mannitol in the cells was also determined [4].

In order to evaluate the $\mathrm{Na}^{+}$dependence of the cellular uptake of $\left[{ }^{14} \mathrm{C}\right]$ levofloxacin, incubation medium containing various $\mathrm{Na}^{+}$concentrations was prepared by replacing $\mathrm{NaCl}$ with $\mathrm{N}$-methylD-glucamine hydrochloride, and the $\mathrm{pH}$ of the medium was adjusted to 6.0 by the addition of $\mathrm{KOH}$. When uptake was measured at an acidic or alkaline $\mathrm{pH}$ ( $\mathrm{pH}$ 5.0-8.0), the $\mathrm{pH}$ of the medium was adjusted using $\mathrm{HCl}$ or $\mathrm{NaOH}$.

The effect of various compounds on the uptake of $\left[{ }^{14} \mathrm{C}\right]$ levofloxacin in LS180 cells on plastic dishes of a multiwell plate was evaluated at $37^{\circ} \mathrm{C}$ in the presence of unlabeled $10-100 \mu \mathrm{M}$ levofloxacin. The cells were first pre-incubated for $15 \mathrm{~min}$ at $37^{\circ} \mathrm{C}$ with $2 \mathrm{ml}$ incubation medium. The incubation medium was replaced with $450 \mu \mathrm{l}$ fresh incubation medium supplemented with various compounds at $5 \mathrm{~min}$ before the addition of $50 \mu \mathrm{l}$ solution of $\left[{ }^{14} \mathrm{C}\right]$ levofloxacin $(0.1 \mu \mathrm{Ci} /$ well). After the cells were incubated with $\left[{ }^{14} \mathrm{C}\right]$ levofloxacin for $15 \mathrm{~min}$ at $37^{\circ} \mathrm{C}$, the amount of $\left[{ }^{14} \mathrm{C}\right]$ levofloxacin in the cells was determined as described above.

\section{Uptake of L-carnitine in LS180 cells}

In order to evaluate the cellular uptake of $\mathrm{L}-\left[{ }^{3} \mathrm{H}\right]$ carnitine in LS180 cells, the cells were first pre-incubated for $15 \mathrm{~min}$ at $37^{\circ} \mathrm{C}$ with $2 \mathrm{ml}$ incubation medium containing unlabeled $1 \mu \mathrm{M}$ L-carnitine. The incubation medium was replaced with $0.5 \mathrm{ml}$ fresh incubation medium containing L- $\left[{ }^{3} \mathrm{H}\right]$ carnitine $(0.1 \mu \mathrm{Ci} /$ well). After the cells were incubated with $\mathrm{L}-\left[{ }^{3} \mathrm{H}\right]$ carnitine for another $15 \mathrm{~min}$ at $37^{\circ} \mathrm{C}$, the amount of $\mathrm{L}-\left[{ }^{3} \mathrm{H}\right]$ carnitine in the cells was determined as described above. To estimate the extracellular trapping of the radio-labeled drug, the amount of $\left[{ }^{14} \mathrm{C}\right]$ mannitol in the cells was also determined.

In order to evaluate the $\mathrm{Na}^{+}$dependence of the cellular uptake of $\mathrm{L}-\left[{ }^{3} \mathrm{H}\right]$ carnitine, incubation medium containing various $\mathrm{Na}^{+}$concentrations was prepared by replacing $\mathrm{NaCl}$ with $\mathrm{N}$-methylD-glucamine hydrochloride, and the $\mathrm{pH}$ of the medium was adjusted to 6.0 by the addition of $\mathrm{KOH}$. When uptake was measured at an acidic or alkaline $\mathrm{pH}(\mathrm{pH} 5.0-8.0)$, the $\mathrm{pH}$ of the medium was adjusted using $\mathrm{HCl}$ or $\mathrm{NaOH}$.

The effect of various compounds on the uptake of L- $\left[{ }^{3} \mathrm{H}\right]$ carnitine in LS180 cells was evaluated at $37^{\circ} \mathrm{C}$ in the presence of unlabeled $1-10 \mu \mathrm{M}$ L-carnitine. The incubation medium was replaced with $450 \mu \mathrm{l}$ fresh incubation medium supplemented with various compounds at $5 \mathrm{~min}$ before the addition of the $50 \mu \mathrm{l}$ solution of $\mathrm{L}-\left[{ }^{3} \mathrm{H}\right]$ carnitine $(0.1 \mu \mathrm{Ci} /$ well $)$. After the cells were incubated with $\mathrm{L}-\left[{ }^{3} \mathrm{H}\right]$ carnitine for $15 \mathrm{~min}$ at $37^{\circ} \mathrm{C}$, the amount of $\mathrm{L}-\left[{ }^{3} \mathrm{H}\right]$ carnitine in the cells was determined as described above.

\section{Statistical analysis}

Values are expressed as the mean \pm SE. In all figures, when error bars are not shown, they are smaller than the symbol. Multiple comparisons

Biopharm. Drug Dispos. 30: 448-456 (2009) DOI: $10.1002 /$ bdd 
were performed using Scheffé's test following one-way ANOVA provided that the variances of groups were similar. If this was not the case, the Scheffé-type test was applied following Kruskal-Wallis analysis. A value of $p<0.05$ was considered to be statistically significant.

\section{Results}

Expression of OATPs and OCTNs mRNA in Caco-2 and LS180 cells

The mRNA levels of OATPs and OCTNs in LS180 cells were compared with those in Caco- 2 cells by real-time PCR (Figure 1). In addition, the mRNA expression of PEPT1 was measured for reference, because the specific transport of Gly-Sar was observed in Caco-2 cells [4]. The expression of PEPT1 mRNA in LS180 cells was much lower than that in Caco-2 cells, and the expression pattern of OATP mRNAs in LS180 cells was markedly different from that in Caco-2 cells (Figure 1). That is, the expression of OATP1A2 mRNA in LS180 cells was much lower than that in Caco-2 cells, and OATP1B1 was not significantly expressed in the two cell lines. The expression of OATP1B3 mRNA in LS180 cells

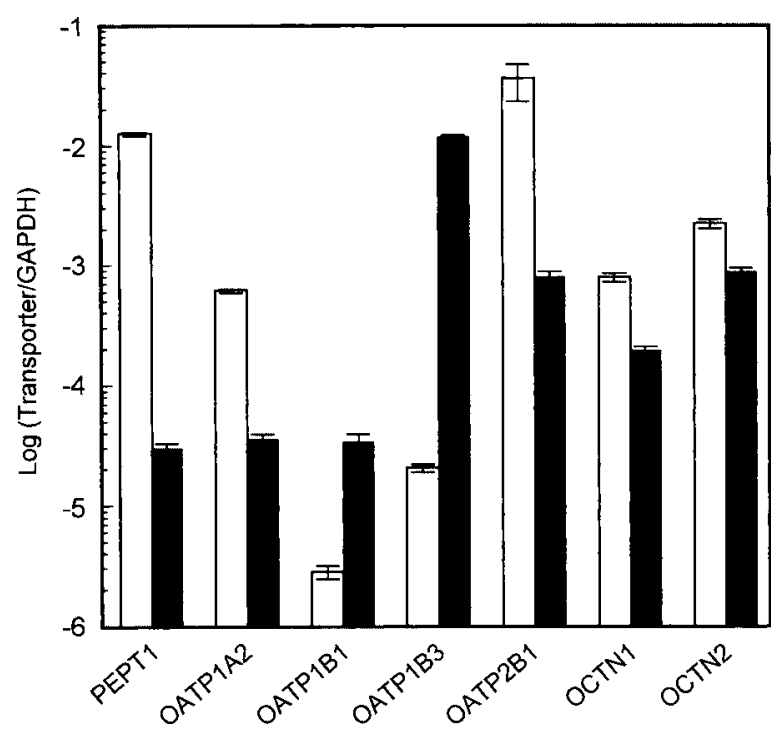

Figure 1. Relative mRNA expression of several SLC transporters in Caco-2 (open columns) and LS180 (closed columns) cells. Each column represents the mean $\pm S E$ for three measurements was higher than that in Caco-2 cells, whereas the expression of OATP2B1 mRNA in LS180 cells was lower than that in Caco-2 cells. On the other hand, the mRNA for OCTN1 and 2 was moderately expressed in both Caco-2 and LS180 cells, and the OCTN1/2 mRNA expression ratio in LS180 cells was similar to that in Caco-2 cells (Figure 1).

\section{Characterization of levofloxacin uptake in LS180} cells

To investigate the existence of a specific transport system for levofloxacin in LS180 cells, the timedependent uptake of $\left[{ }^{14} \mathrm{C}\right]$ levofloxacin in LS180 cells was measured. The uptake of $\left[{ }^{14} \mathrm{C}\right]$ levofloxacin at medium $\mathrm{pH} 6.0$ and $37^{\circ} \mathrm{C}$ was $1.19 \%$, $1.51 \%$ and $1.68 \%$ of the applied dose $(20 \mu \mathrm{M})$ at 5 , 15 and $30 \mathrm{~min}$, respectively, which suggested that the uptake had almost reached a steady state at $15 \mathrm{~min}$ after the start of incubation. Then the effects of extracellular $\mathrm{Na}^{+}$and $\mathrm{pH}$ on the $15 \mathrm{~min}$ uptake of $\left[{ }^{14} \mathrm{C}\right]$ levofloxacin were examined in LS180 cells (Figure 2). The uptake of $\left[{ }^{14} \mathrm{C}\right]$ levofloxacin at $37^{\circ} \mathrm{C}$ was not $\mathrm{Na}^{+}$-dependent in the concentration range of $25-125 \mathrm{~mm}$. On the other hand, $\left[{ }^{14} \mathrm{C}\right]$ levofloxacin uptake in LS180 cells was 1.3-fold higher at physiological $\mathrm{pH} 7.4$ than at acidic pH $5.0(p<0.05)$. In addition, the cellular uptake was markedly decreased at $4^{\circ} \mathrm{C}$ (Figure 2). These results indicated that the uptake of levofloxacin in LS180 cells was mediated by

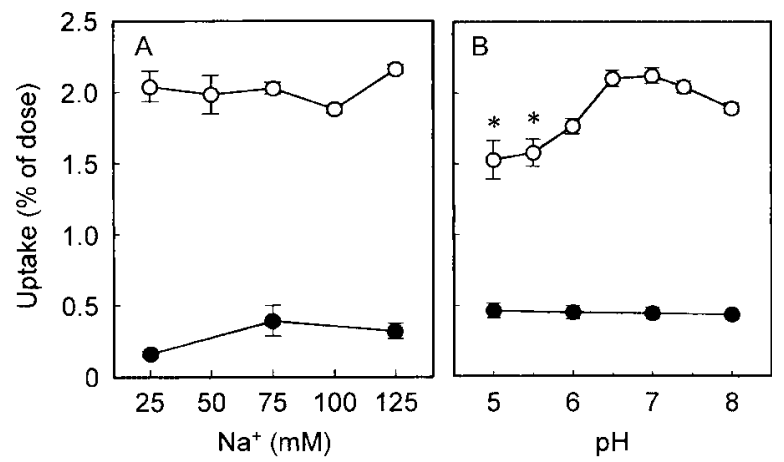

Figure 2. $\mathrm{Na}^{+}$(A) and $\mathrm{pH}$ (B) dependence of cellular uptake of levofloxacin in LS180 cells. Cells were incubated with $\left[{ }^{14} \mathrm{C}\right]$ levofloxacin for $15 \mathrm{~min}$ at $37^{\circ} \mathrm{C}$ (open circles) or $4^{\circ} \mathrm{C}$ (closed circles) in the presence of $20 \mu \mathrm{M}$ unlabeled levofloxacin. Each point represents the mean \pm SE for 4-14 measurements. ${ }^{*} p<0.05$ : significantly different from $\mathrm{pH} 7.4$ at $37^{\circ} \mathrm{C}$ 
a temperature-dependent specific transport system.

The inhibitory effects of nicotine, enalapril, L-carnitine, fexofenadine, and also fluoroquinolones, on the uptake of $\left[{ }^{14} \mathrm{C}\right]$ levofloxacin were evaluated in LS180 cells (Figure 3). Fexofenadine, unlabeled levofloxacin and lomefloxacin decreased the uptake of $\left[{ }^{14} \mathrm{C}\right]$ levofloxacin to $63 \%$, $44 \%$ and $37 \%$ of the control value, respectively. L-Carnitine, enalapril and nicotine significantly decreased the uptake of $\left[{ }^{14} \mathrm{C}\right]$ levofloxacin to $25 \%$, $19 \%$ and $17 \%$ of the control value, respectively (Figure 3). The rank order of inhibitory effects of the four compounds (nicotine>enalapril> L-carnitine $>$ fexofenadine) in LS180 cells was consistent with that in Caco-2 cells [4], which indicated that the specific transport system responsible for the levofloxacin uptake in LS180 cells is identical or similar to that in Caco-2 cells.

Inhibitory effect of various OATP substrates/ inhibitors on levofloxacin uptake in LS180 cells

To evaluate the involvement of OATPs in the levofloxacin uptake in LS180 cells, the effects of

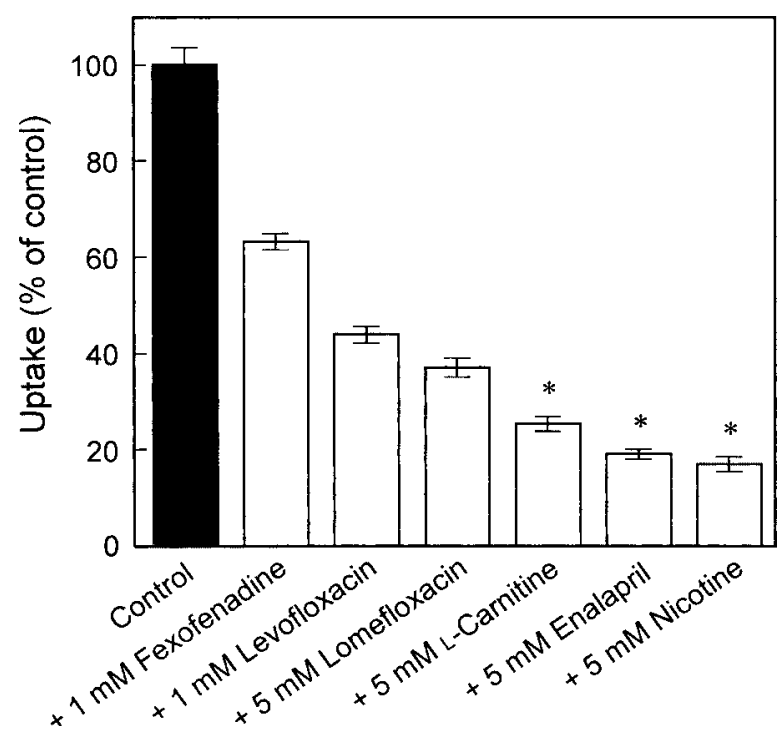

Figure 3. Inhibitory effect of various compounds on cellular uptake of levofloxacin in LS cells. Cells were incubated with $\left[{ }^{14} \mathrm{C}\right]$ levofloxacin for $15 \mathrm{~min}$ in the presence of $100 \mu \mathrm{M}$ unlabeled levofloxacin and various compounds. Closed column represents the mean $\pm \mathrm{SE}$ for 15 measurements, and open columns represent the mean $\pm \mathrm{SE}$ for 6-8 measurements. ${ }^{*} p<0.05$ : significantly different from the control various OATP inhibitors and also carboxylatetype compounds on the cellular uptake of $\left[{ }^{14} \mathrm{C}\right]-$ levofloxacin were further examined. An inhibitor of OATP1B1 and 1B3, rifampicin, decreased the uptake of $\left[{ }^{14} \mathrm{C}\right]$ levofloxacin to $76 \%$ of the control value, whereas other inhibitors of OATP1B1 and 1B3 (bosentan and taurocholic acid) did not inhibit the uptake of $\left[{ }^{14} \mathrm{C}\right]$ levofloxacin (Figure 4). OATP2B1 inhibitors (probenecid and DIDS (4,4'-diisothiocyanatostilbene-2,2'-disulfonic acid disodium salt)) and OATP1A2 inhibitors (hesperidin and naringin) had no significant effect on the uptake of $\left[{ }^{14} \mathrm{C}\right]$ levofloxacin. A carboxylate-type compound, methotrexate, decreased the uptake of $\left[{ }^{14} \mathrm{C}\right]$ levofloxacin to $62 \%$ of the control value, whereas other carboxylate-type compounds (folic acid and sulfasalazine) did not inhibit the uptake of $\left[{ }^{14} \mathrm{C}\right]$ levofloxacin (Figure 4). These results indicated that OATPs did not contribute significantly to the uptake of levofloxacin in LS180 cells.

\section{Comparison of cellular uptake of L-carnitine and levofloxacin in LS180 cells}

To evaluate whether levofloxacin uptake in LS180 cells is mediated by OCTNs, the uptake profile of

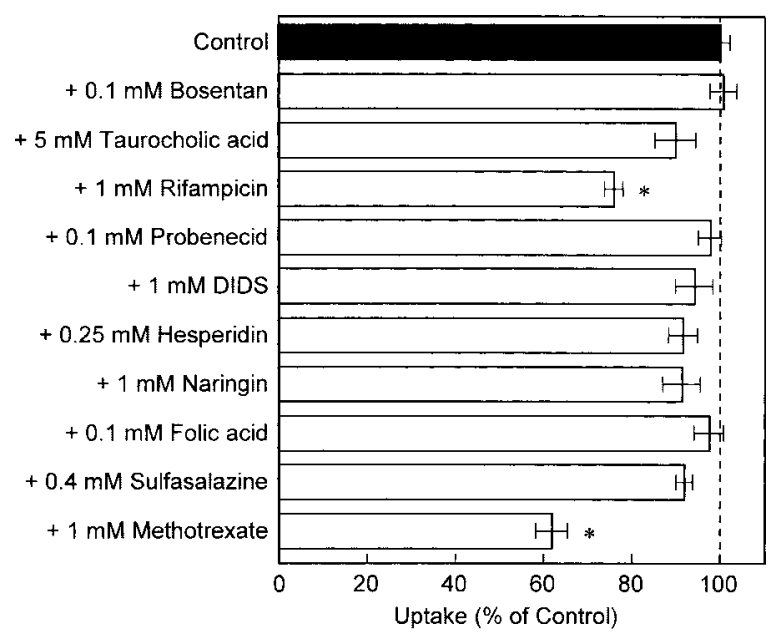

Figure 4. Inhibitory effect of various compounds, including OATP inhibitors, on cellular uptake of levofloxacin in LS180 cells. Cells were incubated with $\left[{ }^{14} \mathrm{C}\right]$ levofloxacin for $15 \mathrm{~min}$ in the presence of $100 \mu \mathrm{m}$ unlabeled levofloxacin and various compounds. Closed column represents the mean \pm SE for 15 measurements, and open columns represent the mean $\pm S E$ for 6-8 measurements. ${ }^{*} p<0.05$ : significantly different from the control 


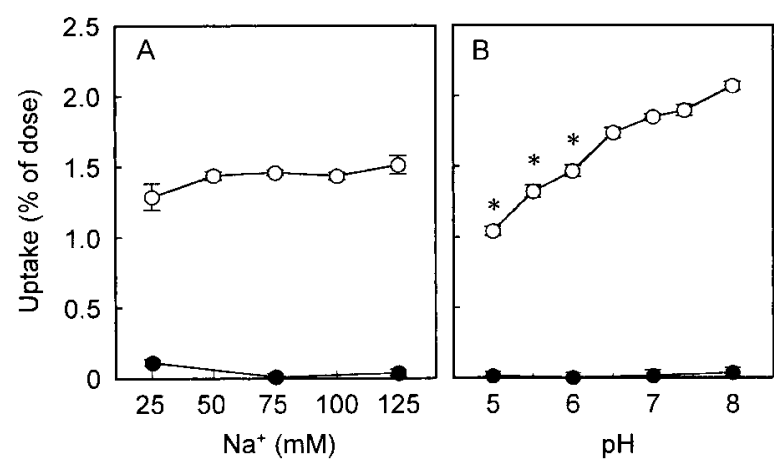

Figure 5. $\mathrm{Na}^{+}$(A) and $\mathrm{pH}$ (B) dependence of cellular uptake of L- $\left[{ }^{3} \mathrm{H}\right]$ carnitine in LS180 cells. Cells were incubated with $\mathrm{L}-\left[{ }^{3} \mathrm{H}\right]$ carnitine for $15 \mathrm{~min}$ at $37^{\circ} \mathrm{C}$ (open circles) or $4^{\circ} \mathrm{C}$ (closed circles) in the presence of $1 \mu \mathrm{M}$ unlabeled L-carnitine. Each point represents the mean $\pm \mathrm{SE}$ for 6-8 measurements. ${ }^{*} p<0.05$ : significantly different from $\mathrm{pH} 7.4$ at $37^{\circ} \mathrm{C}$

L-carnitine in LS180 cells was compared with that of levofloxacin. The change in extracellular $\mathrm{Na}^{+}$concentration between 25 and $125 \mathrm{~mm}$ had no significant effect on the uptake of L- $\left[{ }^{3} \mathrm{H}\right]$ carnitine in LS180 cells at $37^{\circ} \mathrm{C}$ (Figure 5A). Raising the $\mathrm{pH}$ of the medium from 5.0 to 8.0 increased the uptake of L- $\left[{ }^{3} \mathrm{H}\right]$ carnitine at $37^{\circ} \mathrm{C}$ (Figure $5 \mathrm{~B}$ ). On the other hand, the uptake of L- $\left[{ }^{3} \mathrm{H}\right]$ carnitine at $4{ }^{\circ} \mathrm{C}$ was very low (Figure 5). Next, the study evaluated the inhibitory effects of various compounds, which inhibited the levofloxacin uptake, on the uptake of L- $\left[{ }^{3} \mathrm{H}\right]$ carnitine in LS180 cells. Since the uptake of L- $\left[{ }^{3} \mathrm{H}\right]$ carnitine in LS180 cells was almost completely inhibited by $1 \mathrm{~mm}$ fexofenadine (data not shown), the inhibitory effects of the compounds were tested at a concentration of $100 \mu \mathrm{M}$ (Figure 6). Fexofenadine, levofloxacin and unlabeled L-carnitine decreased significantly the uptake of L- $\left[{ }^{3} \mathrm{H}\right]$ carnitine to 77,34 , and $8 \%$ of the control value, respectively; however, lomefloxacin, enalapril and nicotine had little effect on the uptake of L- $\left[{ }^{3} \mathrm{H}\right]$ carnitine (Figure 6). In addition, choline chloride, which is structurally related to L-carnitine, decreased L- $\left[{ }^{3} \mathrm{H}\right]$ carnitine uptake to $78 \%$ and $24 \%$ of the control value at 5 and $50 \mathrm{~mm}$, respectively (Figure 7A). However, the uptake of $\left[{ }^{14} \mathrm{C}\right]$ levofloxacin was only slightly decreased to $91 \%$ of the control value even in the presence of $50 \mathrm{~mm}$ choline chloride (Figure 7B). These findings suggested that OCTNs contributed little to the levofloxacin uptake in LS180 cells.

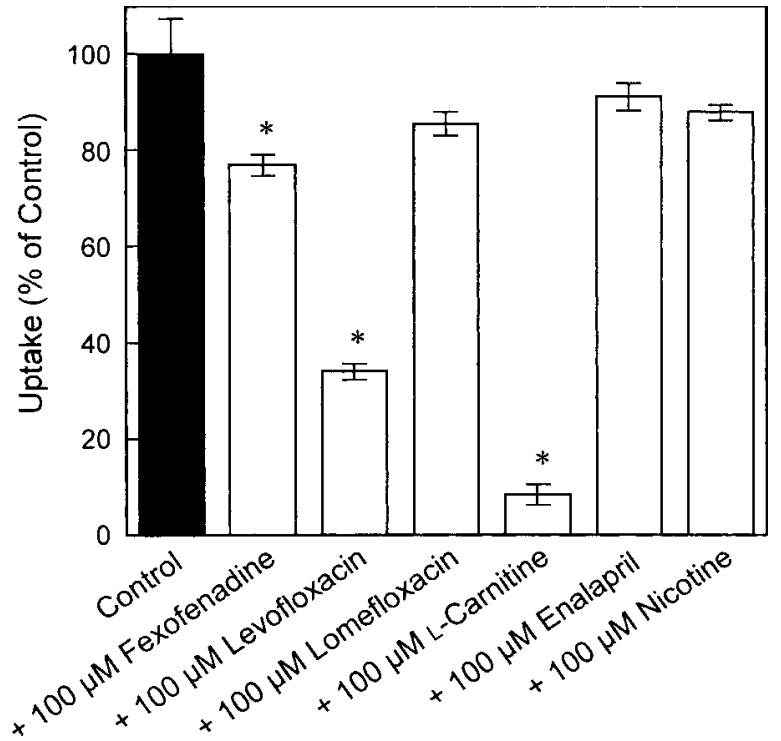

Figure 6. Inhibitory effect of various compounds on cellular uptake of L-carnitine in LS180 cells. Cells were incubated with $\mathrm{L}-\left[{ }^{3} \mathrm{H}\right]$ carnitine for $15 \mathrm{~min}$ in the presence of $1 \mu \mathrm{M}$ unlabeled L-carnitine and $100 \mu \mathrm{M}$ various compounds. Closed column represents the mean $\pm \mathrm{SE}$ for 12 measurements, and open columns represent the mean \pm SE for 5-6 measurements. ${ }^{*} p<0.05$ : significantly different from the control

Inhibitory effect of angiotensin-converting enzyme inhibitors on levofloxacin uptake in LS180 cells

Enalapril significantly inhibited the uptake of levofloxacin in LS180 cells (Figure 3). In order to evaluate the substrate recognition characteristics of the transporter for levofloxacin, the study further evaluated the effect of several ACE inhibitors $(1 \mathrm{mM})$ on the uptake of $\left[{ }^{14} \mathrm{C}\right]$ levofloxacin in LS180 cells (Figure 8). Perindopril and lisinopril had no significant effect on the uptake of $\left[{ }^{14} \mathrm{C}\right]$ levofloxacin in LS180 cells. On the other hand, temocapril, quinapril, captopril and enalapril decreased the uptake of $\left[{ }^{14} \mathrm{C}\right]$ levofloxacin to $59 \%, 54 \%, 51 \%$ and $50 \%$ of the control value, respectively (Figure 8).

\section{Discussion}

Maeda et al. evaluated the levofloxacin uptake activity of Caco- 2 subclones, and selected candidate transporter genes functioning for influx transport of levofloxacin [1]. Based on functional 


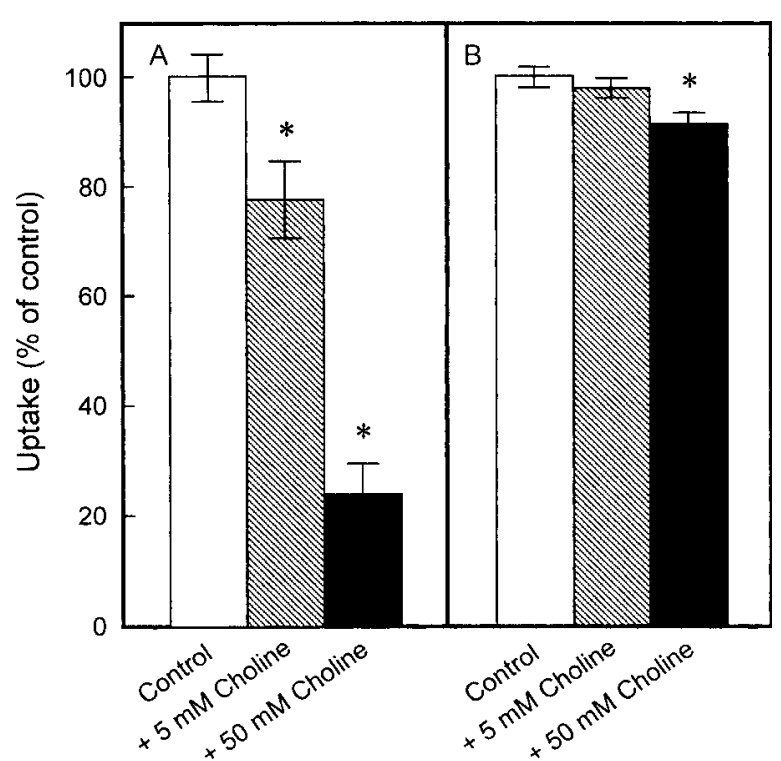

Figure 7. Inhibitory effect of choline chloride on cellular uptake of L-carnitine and levofloxacin in LS180 cells. (A) Cells were incubated with $\mathrm{L}-\left[{ }^{3} \mathrm{H}\right]$ carnitine for $15 \mathrm{~min}$ in the presence of $10 \mu \mathrm{M}$ unlabeled L-carnitine and choline chloride. (B) Cells were incubated with $\left[{ }^{14} \mathrm{C}\right]$ levofloxacin for $15 \mathrm{~min}$ in the presence of $10 \mu \mathrm{M}$ unlabeled levofloxacin and choline chloride. Each column represents the mean \pm SE for six measurements. ${ }^{*} p<0.05$ : significantly different from the control

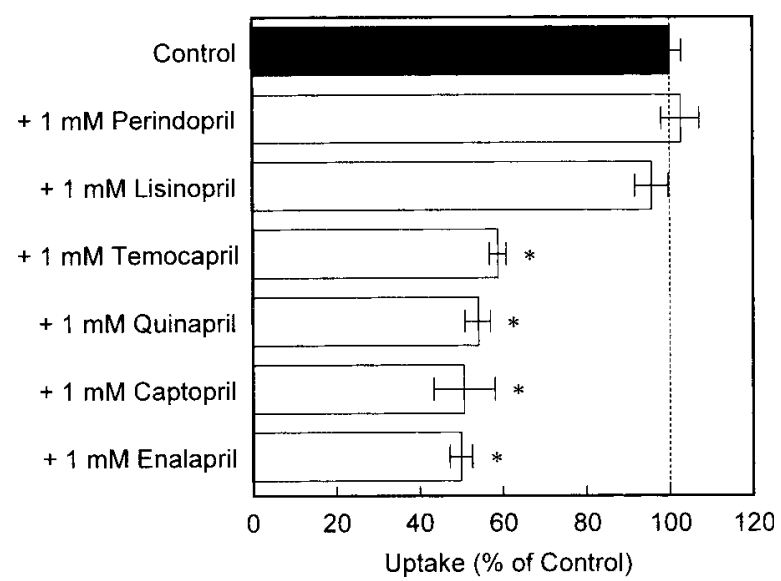

Figure 8. Inhibitory effect of ACE inhibitors on cellular uptake of levofloxacin in LS180 cells. Cells were incubated with $\left[{ }^{14} \mathrm{C}\right]$ levofloxacin for $15 \mathrm{~min}$ in the presence of $100 \mu \mathrm{M}$ unlabeled levofloxacin and $1 \mathrm{~mm}$ ACE inhibitors. Closed column represents the mean $\pm \mathrm{SE}$ for 10 measurements, and open columns represent the mean $\pm \mathrm{SE}$ for 5-7 measurements. ${ }^{*} p<0.05$ : significantly different from the control

analysis of each transporter gene for which a good correlation was found between the mRNA expression level and levofloxacin transport activity in Caco-2 subclones, OATP1A2 was concluded to transport levofloxacin. When OATP1A2 was expressed in Xenopus oocytes, levofloxacin uptake was essentially $\mathrm{pH}$-independent. OATP1A2-mediated uptake of levofloxacin showed a $K_{\mathrm{m}}$ value of $136 \mu \mathrm{m}$ [1]. On the other hand, the apparent uptake of levofloxacin by Caco-2 cells showed high- and low-affinity components with $K_{\mathrm{m}}$ values of 0.489 and $14.6 \mathrm{mM}$, respectively. Accordingly, plural transporters are functional for the transport of levofloxacin in Caco-2 cells, and OATP1A2 is likely to function as a high-affinity transporter [1]. However, it is still unclear which transporter is responsible for the lower-affinity (high-capacity) uptake of levofloxacin in Caco-2 cells.

In the present study, the cellular uptake of levofloxacin was characterized in LS180 cells. Levofloxacin uptake in LS180 cells was temperature-dependent and optimal at neutral $\mathrm{pH}$, but was $\mathrm{Na}^{+}$-independent (Figure 2). The rank order of the inhibitory effects of the four compounds on levofloxacin uptake in LS180 cells was nicotine $>$ enalapril $>$ L-carnitine $>$ fexofenadine (Figure 3 ), which is consistent with that in Caco-2 cells [4]. The findings indicated that the specific transport system responsible for the levofloxacin uptake in LS180 cells was identical or similar to that in Caco-2 cells. The expression level of OATP1A2 mRNA in LS180 cells was much lower than that in Caco-2 cells (Figure 1). In addition, OATP1A2 inhibitors (hesperidin and naringin) did not inhibit the uptake of levofloxacin in LS180 cells (Figure 4). The results also suggested that the uptake of levofloxacin in LS180 cells as well as Caco-2 cells is mainly mediated by a specific transport system other than OATP1A2.

OATP1B1, 1B3 and 2B1 are also expressed in the human intestine [12]. The study further examined whether these OATPs were involved in the specific transport of levofloxacin in LS180 cells. The mRNA levels of OATP1B1, 1B3 and 2B1 in LS180 cells were markedly different from those in Caco-2 cells (Figure 1), and OATP substrates / inhibitors had no systematic inhibitory effect on the uptake of levofloxacin in LS180 cells (Figure 4). In addition, Yamaguchi et al. examined the effect of organic anions on the uptake of levofloxacin in Caco-2 cells, and demonstrated 
that probenecid and DIDS did not inhibit the uptake of levofloxacin in the cells [2]. These findings suggested that levofloxacin uptake in intestinal epithelial cells is mediated by a specific transport system distinct from OATP1B1, 1B3 and $2 \mathrm{~B} 1$.

OCTN2 is a physiologically important carnitine transporter, and is expressed in the human intestine [16]. Hirano et al. investigated the inhibitory effect of levofloxacin on the uptake of L-carnitine in Caco-2 cells, and showed that levofloxacin inhibited the apical uptake of L-carnitine in a non-competitive manner [20]. In the present study, it was found that the characteristics of levofloxacin uptake in LS180 cells were different from those of L-carnitine. That is, nicotine and enalapril inhibited the levofloxacin uptake significantly (Figure 3); however, the inhibitory effect of nicotine on L- $\left[{ }^{3} \mathrm{H}\right]$ carnitine uptake was much less potent than that of unlabeled L-carnitine (Figure 6). Furthermore, choline chloride inhibited the uptake of Lcarnitine, but not of levofloxacin (Figure 7). These findings suggested that the uptake transporter of levofloxacin is distinct from that of Lcarnitine in intestinal epithelial cells.

Many ACE inhibitors are well absorbed from the intestine despite their low lipophilicities, and display absorption rates of $30 \%$ to $100 \%$ of a dose $[15,21]$. However, it is unclear which transporter is involved in the intestinal absorption of ACE inhibitors [15]. The present study additionally examined the effect of several ACE inhibitors on levofloxacin uptake in LS180 cells (Figure 8). In addition to enalapril, temocapril, quinapril and captopril inhibited the uptake of levofloxacin in LS180 cells (Figure 8). To our knowledge, this is the first report demonstrating that the uptake of levofloxacin is affected by several ACE inhibitors in the intestinal epithelial cells. Further systematic studies will be needed to clarify whether levofloxacin was transported by the influx transporter responsible for the intestinal absorption of ACE inhibitors.

In conclusion, the present results indicated that the specific transport system responsible for the levofloxacin uptake in LS180 cells is identical or similar to that in Caco-2 cells, but that OATPs and OCTNs contributed little to the uptake of levofloxacin in the human intestinal epithelial cells.

\section{Acknowledgements}

This work was supported in part by a Grant-inAid for Scientific Research from the Japan Society for the Promotion of Sciences (JSPS) and from the Ministry of Education, Culture, Sports, Science, and Technology (MEXT).

\section{References}

1. Maeda T, Takahashi K, Ohtsu N, et al. Identification of influx transporter for the quinolone antibacterial agent levofloxacin. Mol Pharm 2007; 4: 85-94.

2. Yamaguchi H, Yano I, Saito H, Inui K. Transport characteristics of grepafloxacin and levofloxacin in the human intestinal cell line Caco-2. Eur J Pharmacol 2001; 431: 297-303.

3. Takaai M, Suzuki H, Ishida K, Tahara K, Hashimoto Y. Pharmacokinetic analysis of transcellular transport of levofloxacin across LLC-PK and Caco-2 cell monolayers. Biol Pharm Bull 2007; 30: 2167-2172.

4. Fukumori S, Murata T, Takaai M, Tahara K, Taguchi M, Hashimoto Y. The apical uptake transporter of levofloxacin is distinct from the peptide transporter in human intestinal epithelial Caco-2 cells. Drug Metab Pharmacokinet 2008; 23: 373-378.

5. Gupta A, Mugundu GM, Desai PB, Thummel KE, Unadkat JD. Intestinal human colon adenocarcinoma cell line LS180 is an excellent model to study pregnane $X$ receptor, but not constitutive androstane receptor, mediated CYP3A4 and multidrug resistance transporter 1 induction: studies with anti-human immunodeficiency virus protease inhibitors. Drug Metab Dispos 2008; 36: 1172-1180.

6. Aiba T, Susa M, Fukumori S, Hashimoto Y. The effects of culture conditions on CYP3A4 and MDR1 mRNA induction by $1 \alpha, 25$-dihydroxyvitamin $\mathrm{D}_{3}$ in human intestinal cell lines, Caco-2 and LS180. Drug Metab Pharmacokinet 2005; 20: 268-274.

7. Brandon EF, Bosch TM, Deenen MJ, et al. Validation of in vitro cell models used in drug metabolism and transport studies; genotyping of cytochrome P450, phase II enzymes and drug transporter polymorphisms in the human hepatoma (HepG2), ovarian carcinoma (IGROV-1) and colon carcinoma (CaCo-2, LS180) cell lines. Toxicol Appl Pharmacol 2006; 211: 1-10.

8. Fukumori S, Murata T, Taguchi M, Hashimoto Y. Rapid and drastic induction of CYP3A4 mRNA expression via vitamin D receptor in human intestinal LS180 cells. Drug Metab Pharmacokinet 2007; 22: 377-381.

Biopharm. Drug Dispos. 30: 448-456 (2009) DOI: $10.1002 / \mathrm{bdd}$ 
9. Takaai M, Morishita H, Ishida K, Taguchi M, Hashimoto Y. Contribution of $\mathrm{Na}^{+}$-independent nucleoside transport to ribavirin uptake in the rat intestine and human epithelial LS180 cells. Eur J Pharmacol 2008; 601: 61-65.

10. Fukada A, Saito H, Inui K. Transport mechanisms of nicotine across the human intestinal epithelial cell line Caco-2. J Pharmacol Exp Ther 2002; 302: 532-538.

11. Yasui-Furukori N, Uno T, Sugawara K, Tateishi T. Different effects of three transporting inhibitors, verapamil, cimetidine, and probenecid, on fexofenadine pharmacokinetics. Clin Pharmacol Ther 2005; 77: 17-23.

12. Glaeser H, Bailey DG, Dresser GK, et al. Intestinal drug transporter expression and the impact of grapefruit juice in humans. Clin Pharmacol Ther 2007; 81: 362-370.

13. Thwaites DT, Cavet M, Hirst BH, Simmons NL. Angiotensin-converting enzyme (ACE) inhibitor transport in human intestinal epithelial (Caco-2) cells. Br J Pharmacol 1995; 114: 981-986.

14. Liu L, Cui Y, Chung AY, et al. Vectorial transport of enalapril by Oatp1a1/Mrp2 and OATP1B1 and OATP1B3/MRP2 in rat and human livers. J Pharmacol Exp Ther 2006; 318: 395-402.

15. Knütter I, Wollesky C, Kottra G, et al. Transport of angiotensin-converting enzyme inhibitors by $\mathrm{H}^{+}$ /peptide transporters revisited. J Pharmacol Exp Ther 2008; 327: 432-441.
16. Elimrani I, Lahjouji K, Seidman E, Roy MJ, Mitchell GA, Qureshi I. Expression and localization of organic cation/carnitine transporter OCTN2 in Caco-2 cells. Am J Physiol Gastrointest Liver Physiol 2003; 284: G863-G871.

17. Koepsell H, Lips K, Volk C. Polyspecific organic cation transporters: structure, function, physiological roles, and biopharmaceutical implications. Pharm Res 2007; 24: 1227-1251.

18. Irie $M$, Terada $T$, Tsuda $M$, Katsura $T$, Inui $K$. Prediction of glycylsarcosine transport in Caco-2 cell lines expressing PEPT1 at different levels. Pflugers Arch 2006; 452: 64-70.

19. Moriya $\mathrm{Y}$, Nakamura $\mathrm{T}$, Okamura $\mathrm{N}$, et al. Comparison of synthetic DNA templates with authentic cDNA templates in terms of quantification by real-time quantitative reverse transcription polymerase chain reaction. Biol Pharm Bull 2006; 29: 535-538.

20. Hirano T, Yasuda S, Osaka Y, Kobayashi M, Itagaki S, Iseki K. Mechanism of the inhibitory effect of zwitterionic drugs (levofloxacin and grepafloxacin) on carnitine transporter (OCTN2) in Caco-2 cells. Biochim Biophys Acta 2006; 1758: 1743-1750.

21. Ranadive SA, Chen AX, Serajuddin AT. Relative lipophilicities and structural-pharmacological considerations of various angiotensin-converting enzyme (ACE) inhibitors. Pharm Res 1992; 9: $1480-1486$. 